\title{
NILAI DIDAKTIS UPACARA PACARUAN SASIH KAENEM DI PURA PASEK NGUKUHIN, DESA PAKRAMAN TONJA, KOTA DENPASAR
}

\author{
Oleh: \\ Ni Made Sukrawati \\ Fakultas Pendidikan Agama dan Seni \\ Universitas Hindu Indonesia, Denpasar \\ fpas.unhibali@gmail.com
}

\begin{abstract}
The Pacaruan Sasih Kaenem ceremony in Pura Pasek Ngukuhin, Desa Pakraman Tonja, Denpasar is interesting to be elaborated since it is related to a number of myths and always accompanied by procession of taking down (nedunang) tapakan Barong and Rangda. This local tradition still persists and continues till today because of its didactic values. The ceremonial procession, the didactic value, and the transmission of the didactic value to the Hindus become the main focus of this article. The ceremony of Pacaruan Sasih Kaenem can be divided into three stages, namely the initial procession, the core, and the end. The didactic value found in the ceremony includes the value of education tattwa, susila, and acara. The transmission of the didactic value is done through three methodology, namely religious ideology, myth, and social system.
\end{abstract}

Keywords: didactic value, Pacaruan Sasih Kaenem ceremony

\begin{abstract}
Abstrak
Upacara Pacaruan Sasih Kaenem di Pura Pasek Ngukuhin, Desa Pakraman Tonja, Kota Denpasar menarik diungkap karena berkaitan dengan sejumlah mitos dan selalu disertai prosesi menurunkan (nedunang) tapakan Barong dan Rangda. Tradisi lokal ini masih bertahan dan berlanjut sampai sekarang karena nilai-nilai didaktis di dalamnya. Prosesi upacara, nilai didaktis, dan transmisi nilai didaktis kepada umat Hindu menjadi fokus utama kajian ini. Prosesi upacara Pacaruan Sasih Kaenem dapat dibagi menjadi tiga tahap, yaitu prosesi awal, inti, dan akhir. Nilai didaktis dalam upacara tersebut meliputi nilai pendidikan tattwa, susila, dan acara. Transmisi nilai didaktis dilakukan melalui tiga hal, yaitu melalui ideologi religius, mitos, dan sistem sosial.
\end{abstract}

Kata kunci: Nilai Didaktis, Upacara Pacaruan Sasih Kaenem.

\section{PENDAHULUAN}

\subsection{Latar Belakang Masalah}

Setiap gerak kehidupan masyarakat Bali selalu dikaitkan dengan hubungan transendental sehingga melahirkan kebudayaan Bali yang bercorak sosioreligius. Kebudayaan Bali yang dijiwai nilai-nilai agama Hindu terlihat jelas dalam praktik ritual atau acara umat Hindu di Bali yang lazim disebut yadnya atau yajna. Menurut Sudharta dan Puniatmadja (2001:59), yadnya berarti kurban suci atau persembahan suci berdasarkan cinta kasih. Walaupun ajaran yadnya secara universal merupakan bagian integral dari ajaran agama Hindu, tetapi dalam praktiknya acapkali terdapat perbedaan antara satu daerah 
dan daerah lainnya. Hal ini tidak lepas dari konsep dresta yang berlaku dalam tradisi Hindu dan kebudayaan Bali. Dresta adalah aturan, ketentuan, tradisi adat istiadat yang berlaku di suatu masyarakat (Subagiasta dkk., 1996:7-8) yang dapat dibagi lima, sebagai berikut.

Sastra dresta adalah tradisi dalam agama Hindu yang bersumber pada sumber tertulis yang terdapat pada pustaka-pustaka suci atau sastra agama Hindu. Desa dresta adalah tradisi dalam agama Hindu yang telah menjadi kebiasaan suatu wilayah desa tertentu walaupun tidak tersurat dan tersirat dalam pustaka, namun telah menjadi suatu kesepakatan, serta telah diyakini kebenarannya. Loka dresta adalah tradisi dalam agama Hindu yang berlaku secara umum dalam suatu wilayah tertentu. Kuna dresta atau purwa dresta adalah tradisi dalam agama Hindu yang bersifat turun-temurun dan diikuti secara terus-menerus sejak lama. Kula dresta adalah tradisi dalam agama Hindu yang berlaku bagi kelompok keluarga tertentu.

Setiap dresta pada prinsipnya dapat dijadikan acuan dalam pelaksanaan tradisi keagamaan sehingga melahirkan fenomena ritual yang bersifat lokalistik pada berbagai daerah di Bali. Salah satunya adalah pelaksanaan upacara Pacaruan Sasih Kaenem di Pura Pasek Ngukuhin, Desa Pakraman Tonja, Kecamatan Denpasar Utara, Kota Denpasar. Ada beberapa hal menarik dari upacara tersebut sebagaimana teridentifikasi berikut ini.

Pertama, upacara tersebut dikaitkan dengan kepercayaan terhadap mitos Ratu Gede Nusa. Kepercayaan terhadap mitos menunjukkan bahwa upacara ini tidak didasari oleh teologi Hindu an sich. Menurut Mircea Elliade, mitos adalah ciri religi masyarakat arkhais (pra-agama) yang menggiring manusia dari situasi profan menuju sebuah keadaan yang serba sakral (Susanto, 2002: 97). Kedua, upacara tersebut wajib diikuti dengan tradisi nedunang tapakan Barong Ket dan Rangda yang diarak sepanjang jalan utama Banjar Tegeh Kuri. Kepercayaan ini sejalan dengan pendapat Hadi (2006: 12) bahwa seni dalam ritual merepresentasikan keyakinan mistis pemeluknya. Ketiga, upacara tersebut dilaksankaan di lingkungan Banjar Tegeh Kuri, padahal upacara ini diikuti oleh seluruh krama Desa Pakraman Tonja yang terdiri atas 9 (sembilan) banjar. Fenomena ini menarik ditelusuri karena dalam sistem adat Bali, banjar merupakan sub- sistem dari desa pakraman (Gunadha, 2008: 15). Keempat, upacara tersebut dipusatkan di Pura Pasek Ngukuhin yang tidak menjadi bagian dari kahyangan tiga Desa Pakraman Tonja. Padahal dalam struktur desa pakraman, kahyangan tiga adalah tempat pemujaan dan simbol pemersatu masyarakat desa pakraman dalam pelaksanaan upacara pemujaan sebagai wujud bhakti kepada Tuhan Yang Maha Esa (Astra dkk., 2003: 71).

Pelaksanaan upacara Pacaruan Sasih Kaenem di Desa Pakraman Tonja dengan tradisi yang khas dan unik mengindikasikan seperangkat sistem nilai yang berpengaruh kuat dalam kehidupan masyarakat pendukungnya. Koentjaraningrat (2002: 3) menyatakan, inti kebudayaan adalah sistem nilai yang membangun pola pikir dan perilaku masyarakat termasuk hasil karya yang dihasilkan. Nilai budaya yang hidup dan berkembang di masyarakat merupakan bagian integral dalam pembangunan sistem pendidikan di Indonesia. Hal ini dapat dirujuk dalam Undang-undang Nomor 20 Tahun 2003 tentang Sistem Pendidikan Nasional, pasal 4 ayat (1) yang menyebutkan bahwa pendidikan diselenggarakan secara demokratis dan berkeadilan serta tidak diskriminatif dengan menjunjung tinggi hak asasi manusia, nilai keagamaan, nilai kultural, dan kemajemukan bangsa.

Prinsip penyelenggaraan pendidikan dengan mengembangkan nilai-nilai budaya mengandaikan bahwa proses pendidikan harus mengintegrasikan individu dalam lingkungan alam dan sosialnya. Nilai-nilai budaya dan kearifan lokal dalam kehidupan beragama menjadi bagian integral dalam rangka mewujudkan tujuan pendidikan nasional.

Atas dasar itulah, kajian mengenai nilai didaktis dalam upacara Pacaruan Sasih Kaenem di Desa Pakraman Tonja menarik dilakukan. Melalui pengungkapan terhadap proses upacara, nilai didaktis di dalamnya, dan transmisi nilai didaktis kepada umat Hindu, kiranya kajian ini dapat menjangkau sejumlah aspek pendidikan yang terintegrasi satu sama lain. Pertama, menggali tradisi lokal keagamaan umat Hindu di Bali; kedua, mengetahui tingkat elastisitas dan strategi kebertahanan budaya lokal dalam perubahan zaman; dan ketiga memahami nilai didaktis dalam tradisi lokal yang dapat ditransformasikan dalam pengembangan pendidikan agama dan keagamaan Hindu. 


\subsection{Kajian Pustaka, Konsep, dan Teori}

Kajian tentang upacara Pacaruan Sasih Kaenem di Desa Pakraman Tonja sesungguhnya telah dilakukan oleh beberapa ilmuwan terdahulu. Karsana (2012) mengungkapnya dalam sebuah tesis yang memfokuskan pada tarian Barong Ket dan Rangda dalam upacara Pacaruan Sasih Kaenem di Desa Pakraman Tonja ditinjau perspektif agama dan kebudayaan. Geriya dkk. (2010), juga menyebutkan bahwa Barong Ket dan Rangda di Desa Pakraman Tonja memiliki keunikan dan kekhasan tersendiri sehingga patut dilestarikan. Sukarma, dkk. (2014), mengkaji keberadaan Barong dan Rangda di Desa Pakraman Tonja sebagai salah satu sistem religi yang unik di Kota Denpasar. Dengan demikian, upacara Pacaruan Sasih Kaenem dalam perspektif pendidikan Hindu belum pernah diungkap. Kajian ini menekankan aspek nilai didaktis dan transmisinya pada umat Hindu.

Nilai (value) dipandang sebagai inti kebudayaan atau lapisan paling abstrak dari kebudayaan. Sistem nilai (value system) memiliki kekuatan untuk mengatur, mengendalikan, dan memberikan arah pada perilaku atau perbuatan dari individu dan masyarakat (Koentjaraningrat, 2002:5-6). Sementara itu, didaktis berarti segala sesuatu yang bersifat mendidik (KBBI, 2005:326). Pengungkapan nilai didaktis dari sebuah tradisi diarahkan untuk memahami ide dan gagasan dalam tradisi tersebut, baik berupa pandangan filosofis, etis, maupun organis yang memperkaya kehidupan budaya dan rohani masyarakat.

Nilai didaktis bertalian erat dengan esensi pendidikan, seperti terungkap dalam Undangundang Republik Indonesia Nomor 20 Tahun 2003 tentang Sistem Pendidikan Nasional, bahwa pendidikan adalah usaha sadar dan terencana untuk mewujudkan suasana belajar dan proses pembelajaran agar peserta didik secara aktif mengembangkan potensi dirinya untuk memiliki kekuatan spiritual keagamaan, pengendalian diri, kepribadian, kecerdasan, akhlak mulia, serta keterampilan yang diperlukan dirinya, masyarakat, bangsa, dan negara. Pengertian ini menegaskan bahwa pendidikan mencakup proses pengubahan sikap dan tingkah laku manusia; pengembangan potensi diri; dan pendewasaan diri secara intelektual, moral, dan spiritual (Mulyasa, 2008: 21). Senada dengan itu, Kaswardi (1993: 13) menyatakan bahwa nilai didaktis adalah penanaman dan pengembangan nilai-nilai pada diri sesorang melalui proses pendidikan dan pengajaran sehingga mampu menemukan jati dirinya, baik secara individual maupun sosial.

Berkaitan dengan pendapat tersebut, David (2000:9) mendefinisikan nilai didaktis adalah nilai pendidikan yang dapat mengembangkan kemampuan seseorang dan selanjutnya mampu mengaktualisasikan kemampuan itu melalui pertimbangan nilai atau aturan moral. Nilai didaktis bertujuan untuk melembagakan kerangka tindakan manusia dalam kehidupan sosial masyarakat. Nilai didaktis mencakup keseluruhan aspek kehidupan masyarakat dalam memberikan penyadaran bahwa nilai kebenaran berlaku melalui proses pertimbangan niali yang terarah dan pembiasaan tindakan secara konsisten. Mulyana (2011: 103) menegaskan bahwa nilai didaktis adalah nilai untuk memanusiakan manusia. Nilai didaktis memosisikan manusia sebagai mahkluk yang memiliki kemampuan untuk hidup serasi dan selaras dengan lingkungan alam, sosial, dan perkembangan teknologi. Nilai didaktis harus dikembangkan dalam rangka membentuk manusia bermartabat dengan menjadikan kemanusiaan pada posisi tertinggi.

Nilai didaktis dari sebuah tradisi sesungguhnya berkaitan dengan definisi kebudayaan sebagai hasil proses belajar. Ihromi (ed.) (2006: 18) menyatakan bahwa kebudayaan merupakan cara berlaku, kepercayaan-kepercayaan, sikapsikap, dan hasil karya yang diperoleh dari proses belajar. Konsep ini mengandaikan bahwa suatu tradisi tidak diterima begitu saja, tetapi diwariskan melalui transmisi nilai-nilai didaktis di dalamnya. Sifat mendidik dari nilai budaya adalah fungsi dan peranannya dalam membentuk sistem gagasan, aktivitas, dan hasil karya masyarakat. Upacara keagamaan Hindu memiliki nilai didaktis yang mencakup aspek intelektual, moral, dan spiritual dalam kehidupan beragama umat Hindu.

Dalam kajian ini, upacara Pacaruan Sasih Kaenem sebagai objek material merupakan salah satu jenis upacara keagamaan yang dilaksanakan umat Hindu, khususnya di Desa Pakraman Tonja. Upacara berarti tata cara pelaksanaan acara agama Hindu yang menyangkut tempat upacara (lokasi), saat upacara (durasi), suasana upacara (situasi), rangkaian upacara (prosesi), ucapan upacara (resitasi), alat upacara 
(sakramen), dan bunyi-bunyian upacara (instrumen) (Sudharma, 2000:3). Pacaruan adalah prosesi upacara caru, yaitu persembahan kepada para bhuta atau kekuatan-kekuatan jahat yang dapat mengganggu manusia. Sementara itu, sasih kaenem adalah bulan keenam dalam sistem penghitungan kalender Bali. Dengan demikian, upacara Pacaruan Sasih Kaenem adalah upacara bhuta yadnya yang dilaksanakan setiap bulan keenam dalam sistem kalender Bali.

Pengungkapan nilai didaktis dalam upacara Pacaruan Sasih Kaenem di Pura Pasek Ngukuhin, Desa Pakraman Tonja tentu diperlukan sejumlah teori untuk menganalisisnya. Mengingat objek kajian ini adalah upacara keagamaan Hindu sehingga teori religi yang berorientasi pada sistem ritus dan upacara dipandang tepat untuk digunakkan. Menurut Preusz (dalam Koenjaraningrat, 1987:69), pusat setiap sistem religi dan kepercayaan adalah ritus dan upacara. Manusia beranggapan bahwa dengan ritus tertentu akan dapat mencapai tujuan hidupnya, baik yang bersifat material maupun spiritual. Suatu ritus atau upacara religi biasanya menggunakan berbagai macam sarana dan peralatan, tempat atau gedung pemujaan, patung dewa, patung orang suci, gamelan suci, dan lain-lain. Para pelaku upacara seringkali harus menggunakan pakaian yang juga dianggap mempunyai sifat suci (Koentjaraningrat, 1987: 81). Teori sistem ritus dan upacara ini membuktikan bahwa setiap sarana ritual sejak awal keberadaan manusia (agama) telah diperhitungkan penggunaanya untuk membantu kesulitan manusia dalam memecahkan berbagai masalah kehidupannya. Teori ini dapat digunakan untuk mengkaji prosesi upacara Pacaruan Sasih Kaenem di Pura Pasek Ngukuhin, Desa Pakraman Tonja, Kota Denpasar.

Kemudian, untuk mengungap nilai didaktis upacara tersebut digunakan teori nilai (theory of value) yang menghubungkan antara nilai dengan minat atau kepentingan; serta pengendalian nilai-nilai yang berhubungan dengan segi objektif sebuah institusi. Nilai dipandang bersifat kognitif dan non-kognitif; atau bersifat objektif dan subjektif (Bagus, 2002: 721). Seturut dengan itu, Alhaj (dalam Zamroni, 1994: 10-12) membagi nilai menjadi tiga, yaitu (1) nilai material adalah segala sesuatu yang berguna bagi manusia; (2) nilai vital adalah segala sesuatu yang berguna bagi manusia untuk dapat menga- dakan kegiatan dan aktivitas, dan (3) nilai kerohanian adalah segala sesuatu yang berguna bagi rohani manusia. Nilai kerohanian ini dapat dibedakan lagi menjadi empat, yaitu: pertama, nilai kebenaran yang bersumber pada akal budi manusia; kedua, nilai keindahan yang bersumber pada unsur-unsur rasa indah manusia; ketiga, nilai kebaikan atau moral yang bersumber pada unsur kodrat manusia; dan keempat, nilai religius yang bersumber dari unsur ketuhanan, kerohaniaan yang tinggi dan mutlak, serta kepercayaan.

Berkenaan dengan nilai kerohanian, Taragina (dalam Sueni, 2012:43) juga menyebutnya nilai etis-religius, yakni nilai dari suatu aktivitas atau hasil karya yang merefleksikan berbagai hal yang bersangkut-paut dengan etika, moral dan agama. Di lain pihak, Spranger (dalam Warsana, 2007: 45) menyebutnya nilai agama, yaitu suatu objek disebut bernilai jika berguna dalam pelaksanaan ajaran agama tertentu. Berpijak pada beberapa pendapat di atas, maka nilai didaktis yang dikaji dalam upacara Pacaruan Sasih Kaenem terutama adalah nilai kerohanian yang tercakup di dalamnya nilai kebenaran, keindahan, moral, dan religius.

Sementara itu, transmisi nilai didaktis dalam upacara Pacaruan Sasih Kaenem diungkap dengan teori konstruktivistik. Teori ini dilandasi oleh filsafat pendidikan konstruktivisme, yaitu landasan berpikir (filosofis) dalam pembelajaran kontekstual. Pengetahuan bukanlah seperangkat fakta-fakta, konsep, atau kaidah yang siap untuk diambil dan diingat, tetapi manusia harus mampu mengkonstruksi pengetahuan itu dan memberi makna melalui pengalaman nyata (Suparno, 1997:4). Pandangan ini bertalian erat dengan kritik Freire (1984:38) terhadap behaviorisme pendidikan, sebagai berikut.

“...Dengan memberikan rumusan-rumusan yang harus diterima dan dihafalkan oleh para murid, kita tidak memberinya perangkat untuk berpikir otentik. Kita tidak memungkinkan asimilasi muncul dari pencarian, dari usaha untuk mencipta lagi dan menemukan kembali."

Dengan membandingkan gagasan Paulo Freire dan Ki Hajar Dewantara, Yamin (2009: 23) menegaskan pentingnya mengubah paradigma pendidikan dari behaviorisme ke kon- 
struktivisme yang lebih dapat memosisikan manusia sebagai subjek pendidikan. Hal ini sejalan dengan pandangan kaum konstruktivistik bahwa peserta didik dipandang sebagai pembelajar yang dalam dirinya sudah memiliki motivasi untuk mengetahui dan akan memahami sendiri konsekuensi dari tindakannya (Surakhmad, 2003: 18; Budiningsih, 2005: 25). Jean Peaget menyatakan bahwa peserta didik mengkonstruksi sendiri pengetahuannya melalui pengalaman bertemu dengan objek-objek yang ada di lingkungannya. Proses konstruksi akan terjadi melalui 3 (tiga) tahapan, yaitu asimilasi, akomodasi, dan ekuilibrasi. Asimilasi adalah proses pengintegrasian atau penyatuan informasi baru ke dalam struktur kognitif yang telah dimiliki oleh individu. Akomodasi merupakan proses penyesuaian struktur kognitif ke dalam situasi yang baru. Ekuilibrasi adalah penyesuaian berkesinambungan antara asimilasi dan akomodasi. Agar seseorang dapat mengembangkan pengetahuannya sekaligus menjaga stabilitas mentalnya, diperlukan proses penyeimbangan antara lingkungan luar dengan struktur kognitif yang ada di dalam dirinya secara terus-menerus (Budiningsih, 2005: 12).

Bertalian dengan itu, Maliki (2010: 204) menyatakan bahwa pendidikan harus mampu memahami faktor-faktor instrinsik yang ada dalam diri peserta didik. Oleh karena itu, pendidikan harus dimulai dari self concept (konsep diri) siswa. Dalam pandangan konstruktivistik, siswa dinilai memiliki potensi instinsik dalam menciptakan lingkungan belajar yang kondusif. Pembelajaran dipandang sebagai proses yang dikendalikan sendiri (self-regulated) oleh peserta didik. Persepektif ini menekankan pada proses pembelajaran kolaboratif sehingga proses pembelajarannya dapat dilakukan di mana saja bisa secara bersama-sama (melalui proses sosial). Anak-anak diberi fasilitas untuk berinteraksi dengan lingkungannya disertai dengan proses refleksi diri (self-reflexion). Vygotsky (dalam Maliki, 2010:206) menyatakan bahwa pendidikan dalam pandangan konstruktivitik memfokuskan pada peran faktor sosial dan budaya dalam pengembangan pembelajaran. Vygotsky meyakini bahwa proses sosial merupakan bagian tidak terpisahkan dari proses pembelajaran. Fokus pengetahuan menurutnya terletak pada interaksi sosial yang nantinya membentuk perkembangan kognisi dari pembelajar sehing- ga interaksi sosial menjadi kata kunci dalam proses pembelajaran.

\section{II.PEMBAHASAN}

\subsection{Prosesi Upacara Pacaruan Sasih Kae- nem di Desa Pakraman Tonja}

Upacara Pacaruan Sasih Kaenem merupakan bagian dari acara agama Hindu, yaitu bhuta yadnya. Bhuta yadnya adalah upacara yang ditujukan kepada makhluk-makhluk bawah (bhuta kala), sekaligus bertujuan untuk mengharmoniskan alam semesta. Dalam yadnya tersebut terkandung rangkaian upacara dan upakara. Upacara berarti rangkaian tindakan dalam kegiatan ritual, sedangkan upakara berarti sarana kebaktian (Sura, dkk., 2002: 127). Ini sebabnya, dalam setiap prosesi yadnya selalu terdapat rangkaian prosesi kegiatan (upacara), juga sarana dan prasarana ritual (upakara). Prosesi upacara Pacaruan Sasih Kaenem di Pura Pasek Ngukuhin, Desa Pakraman Tonja adalah sebagai berikut.

Prosesi Awal. Prosesi ini diawali dengan penentuan waktu pelaksanaan upacara. Upacara Pacaruan Sasih Kaenem dilaksanakan secara rutin setiap tahun, tepatnya setiap kajeng kliwon sasih kaenem yang berdekatan dengan hari tilem. Penetapan sasih kaenem didasari mitos tentang Ida Ratu Gede Nusa atau dikenal juga dengan Ratu Gede Mecaling atau Ratu Gede Dalem Ped. Dalam mitos tersebut, kedatangan Ratu Gede Nusa ke Bali daratan adalah untuk mencari makanan dan menyebarkan penyakit (grubug) sehingga pada sasih kaenem umat Hindu perlu melaksanakan upacara bhuta yadnya.

Setelah waktu pelaksanaan upacara Pacaruan Sasih Kenem ditetapkan maka segala persiapan upacara pun mulai dilaksanakan. Persiapan yang dilakukan terutama adalah mendirikan sanggah cucuk (nancepang sanggah cucuk) di depan rumah masing-masing. Dalam sanggah cucuk tersebut dipersembahkan banten sodan yang dilanjutkan dengan menghaturkan segehan dan matabuh arak dan brem. Selain di sanggah cucuk, krama juga menghaturkan (maturan) sodaan dan segehan di sanggah dan merajan keluarga masing-masing. Di samping itu, tahapan persiapan upacara juga dilaksanakan di lokasilokasi upacara akan berlangsung, yaitu di natar Jeroan Pura Ngukuhin, di pertigaan Oongan, dan di perempatan Tegeh Kuri - Benculuk. Persiapan yang dilakukan di lokasi tersebut dilak- 
sanakan oleh krama terutama mempersiapkan banten dan prasarana upacara lainnya.

Prosesi Inti. Sekitar pukul 19.00 Wita krama Desa Pakraman Tonja sudah berkumpul di Pura Pasek Ngukuhin. Prosesi upacara diawali dengan Nedunang Tapakan Barong Ket dan Rangda. Untuk melaksanakan upacara ini dipersiapkan sarana banten panyamblehan dan ngaturang labaan di depan Gedong Ratu Ngurah (Barong Ket) dan Ratu Ayu (Rangda). Setelah itu, seluruh perangkat upacara yang terdiri atas penari Barong Ket, penari Rangda, dan beberapa papatih melaksanakan persembahyangan (muspa), matirta, dan mabija. Setelah itu, mulailah tapel Barong Ket dan Rangda, serta keris diturunkan dari gedong oleh Jero Mangku Terima dan diberikan kepada masing-masing penari. Setelah semua siap dengan sarananya masing-masing, mulailah tapel Barong Ket dan Rangda tersebut dikenakan (nyaluk).

Setelah prosesi nyaluk tapel ini, upacara Pacaruan Sasih Kaenem sudah siap dilaksanakan dan gambelan gong dan bleganjur juga mulai dibunyikan untuk mengiringi Barong Ket dan Rangda menari seperti lumrahnya gerakan tarian Barong dan Rangda. Kemudian, setelah Barong Ket dan Rangda sampai di lokasi pacaruan, Jro Mangku Desa Tonja melakukan pemujaan (nganteb) banten caru menghadap ke timur. Barong Ket dan Rangda berdiri di sebelah timur banten caru (posisi ulu) dengan posisi Barong Ket di sebelah kanan dan Rangda di sebelah kiri. Setelah Jro Mangku Desa Tonja selesai nganteb banten caru, mulailah Jro Mangku Barong mengucapkan mantra-mantra suci dari dalam tapel Barong Ket sehingga seolah-olah Barong Ket itu yang mengucapkan mantra. Mantra dari Barong Ket inilah yang diyakini masyarakat Tegeh Kuri sebagai pamuput (menyelesaikan) seluruh prosesi pacaruan.

Seusai Jro Mangku Barong menguncapkan mantra pamuput caru maka Barong Ket dan Rangda memasuki areal banten caru untuk melakukan prosesi napak yang berarti menyentuh dengan kaki, atau menginjak. Artinya, prosesi utama napak caru adalah Barong Ket dan Rangda memasuki areal banten caru yang dibatasi dengan klangsah dan menginjakkan kakinya di sana sebanyak 3 (tiga) kali. Bersamaan dengan prosesi ini, mulailah para Papatih mengalami kerauhan dan ngurek dirinya sendiri dengan keris yang sudah diambil dari Gedong Ratu Ngu- rah dan Ratu Ayu. Prosesi ngurek ini berlangsung antara 10 sampai 15 menit dan menciptakan suasana yang mencekam dan mistis. Prosesi ini berakhir setelah Jro Mangku Desa memercikkan (ngetisin) tirta suci kepada para papatih yang kerauhan. Setelah itu barulah seluruh umat melaksanakan upacara muspa ngayabang caru, matirta, dan mabija, sekaligus menandai bahwa satu tahap upacara Pacaruan Sasih Kaenem di Pura Pasek Ngukuhin telah selesai.

Prosesi selanjutnya adalah Ida Bhatara Malancaran, yakni melakukan perjalanan suci (malancaran). Dalam prosesi ini, penari Barong Ket dan Rangda keluar dari lokasi Pura Pasek Ngukuhin menuju ke pertigaan Oongan. Selama proses malancaran ini penari Barong Ket dan Rangda menari sambil berjalan mengikuti irama gambelan Bleganjur yang mengiringinya. Setibanya di pertigaan Oongan, dilaksanakan upacara pacaruan yang pada prosesinya sama seperti di Pura Pasek Ngukuhin, yakni nganteb banten caru, mengucapkan mantra pamuput ca$r u$, dan napak caru. Prosesi dilanjutkan menuju perempatan Tegeh Kuri - Benculuk, dengan prosesi pacaruan yang tidak jauh berbeda dengan sebelumnya. Dengan berakhirnya prosesi di tempat ini, maka prosesi dilanjutkan ke Pura Kahyangan Bantas.

Prosesi upacara di Pura Kahangan Bantas dilakukan karena adanya ikatan historis religius antara Ida Bhatara di Pura Pasek Ngukuhin dengan Ida Bhatara di Pura Kahyangan Bantas. Pada saat bersamaan, juga panyungsung Kahyangan Bantas sedang melakukan Pacaruan Sasih Kaenem. Akan tetapi, dalam prosesi tersebut tidak ada upacara napak caru karena memang pacaruan di Kahyangan Bantas dilakukan oleh panyungsungnya sendiri. Walaupun demikian, setelah upacara pacaruan selesai umat Hindu yang mengiringi Ida Bhatara dari Tegeh Kuri ikut muspa ngayabang caru di Kahyangan Bantas. Prosesi ini mengingatkan pada keyakinan magis krama Banjar Tegeh Kuri bahwa Ida Ratu Ayu Maniksaya (tapakan Rangda) yang dipersunting oleh Ida Ratu Ngurah (tapakan Barong Ket) konon berasal dari Pura Kahyangan Bantas.

Prosesi Akhir. Prosesi ini ditandai dengan kembali tapakan Barong Ket dan Rangda ke Pura Pasek Ngukuhin. Sesampainya di areal jeroan pura dilaksanakan upacara ngelinggihang Barong Ket dan Rangda kembali ke Gedong Ratu Ngurah dan Ratu Ayu. Sebelum penari Barong 
Ket dan Rangda melepas tapel yang dikenakan, maka Jro Mangku Desa Tonja melaksanakan upacara panyamblehan siap selem (ayam hitam) terlebih dahulu. Kemudian, tapel tersebut dilepaskan dan dikembalikan ke tempat semula bersama keris yang digunakan para papapatih. Upacara panyineb Pacaruan Sasih Kaenem di Pura Pasek Ngukuhin dilaksanakan dengan menggunakan Banten Panglebar. Bersamaan dengan upacara panyineb ini, seluruh umat Hindu yang terlibat dalam pelaksanaan upacara Pacaruan Sasih Kaenem melaksanakan muspa bersamasama sebagai ucapan terima kasih atas suksesnya upacara tersebut. Dengan demikian, seluruh rangkaian prosesi upacara Pacaruan Sasih Kaenem di Desa Pakraman Tonja telah berakhir.

\subsection{Nilai Didaktis dalam Upacara Pacaru- an Sasih Kaenem}

Upacara keagamaan, sebagaimana Pacaruan Sasih Kaenem di Pura Pasek Ngukuhin, Desa Pakraman Tonja dipandang sebagai salah satu cara manusia religius untuk mendekatkan diri dengan Yang Sakral. Oleh karena itu, nilai yang mendasari ritual keagamaan tidak dapat lepas dari kepercayaan manusia terhadap adanya Tuhan. Kepercayaan terhadap Tuhan tidak hanya terjelma dalam pikiran atau intuisi, tetapi dalam wujud tindakan yang realistis dan dinamis berupa upacara keagamaan. Seturut dengan itu, Lubis, dkk. (2007:36) menyatakan bahwa upacara keagamaan merupakan cara umat beragama untuk menghubungkan diri dengan Yang Gaib. Tidak hanya itu, tradisi keagamaan selalu dilaksanakan dengan aturan-aturan moral yang ketat, seperti aturan tentang kesucian, tata cara dan urutan upacara, disiplin diri, dan ketundukan pada aturan yang berlaku dalam pelaksanaan ritual tersebut. Seluruh nilai tersebut dibingkai dalam pelaksanaan upacara (acara) dengan tuntunan dan tatanan yang jelas dan pasti. Nilai-nilai didaktis yang terkandung dalam upacara Pacaruan Sasih Kaenem di Pura Pasek Ngukuhin, Desa Pakraman Tonja dapat dikaji dalam tiga koridor kerangka agama Hindu, yaitu tattwa, susila, dan acara.

Nilai pendidikan tattwa dalam upacara Pacaruan Sasih Kaenem di Pura Pasek Ngukuhin, Desa Pakraman Tonja terutama dapat dilihat dengan keberadaan tapakan Barong Ket dan Rangda sebagai simbol (niyasa) ketuhanan yang dipuja dalam upacara tersebut. Pacaruan Sasih Kaenem merupakan salah satu jenis upacara bhuta yadnya, yaitu kurban suci yang bertujuan untuk membersihkan alam semesta beserta isinya dari segala pengaruh jahat (asura) serta memberi "somya" agar pengaruh-pengaruh jahat tersebut dapat dinetralisir menjadi kekuatan yang baik (daiva) (Tim, 2002:109). Dalam prosesi upacara tersebut, Ista Dewata yang paling berperan adalah Bhatara Siwa dan Bhatari Durga yang diwujudkan dalam Barong Ket dan Rangda. Secara teologis, keduanya merupakan perwujudan dari Bhatara dan Bhatari yang oleh masyarakat setempat disebut Ratu Bagus (Barong Ket) dan Ratu Ayu (Rangda). Keduanya adalah perwujudan dari Ida Sang Hyang Widhi Wasa sehingga sisi rwa bhineda tidaklah dimaksudkan sebagai pertentangan, melainkan keduanya merupakan unsur esensial kehidupan.

Dengan demikian, nilai pendidikan tattwa yang terkandung dalam upacara Pacaruan Sasih Kaenem adalah pemujaan kepada Bhatara Siwa dan Bhatari Durga sebagai manifestasi Ida Sang Hyang Widhi Wasa/Tuhan Yang Maha Esa dalam fungsinya sebagai pelenyap (nyomya) segala pengaruh jahat (bhuta atau asura). Kepercayaan ini mendidik umat Hindu agar selalu memuja Tuhan dalam berbagai manifestasi-Nya, serta menanamkan nilai-nilai ketuhanan dalam dirinya. Dengan menghadirkan Tuhan dalam kehidupan, niscaya manusia akan terhindar dari berbagai penderitaan (duhka) serta kehidupannya akan berjalan terarah karena selalu dibimbing oleh dharma (kebenaran).

Nilai pendidikan susila meliputi tiga aspek, yaitu pikiran, perkataan, dan perbuatan (trikaya parisudha). Penyucian pikiran, perkataan, dan perbuatan adalah inti ajaran susila agama Hindu sehingga seluruh nilai pendidikan susila diarahkan pada ketiga aspek tersebut. Penyucian pikiran dalam konteks upacara Pacaruan Sasih Kaenem tampak dari ketulusan umat Hindu untuk melaksanakan yadnya tersebut. Setiap waktu pelaksanaan yadnya ini akan datang, umat sudah memikirkan berbagai hal yang terbaik demi suksesnya yadnya tersebut. Penyucian perkataan ditunjukkan dengan adanya aturan-aturan dalam melaksanakan upacara Pacaruan Sasih Kaenem, di antaranya tidak berlaku marah serta mengeluarkan kata-kata yang tidak senonoh "aywa mangambekang krodha mwang ujar gangsul", tidak mengucapkan kata-kata kasar (memisuh), bertengkar (mejajal), memfitnah 
(ngomongan jelek timpal), berkata bohong (bogbog), bahkan tidak dibenarkan pula berkata-kata atau bersuara dengan nada yang keras (nengkik). Penyucian perbuatan (kàyika parisuddha) dilakukan dengan mengendalikan diri dari perbuatan terlarang dan dapat mencemari (ngeletehin) kesucian yadnya. Dalam pelaksanaan upacara Pacaruan Sasih Kaenem umat Hindu melaksanakan aktivitas upacara sesuai aturan-aturan yang berlaku, seperti tidak dibenarkan berkelahi, lebih-lebih sampai mengeluarkan tetesan darah pada saat upacara berlangsung; tidak dibenarkan menyusui bayi pada saat menyiapkan sarana upacara; demikian pula tidak dibenarkan untuk menguraikan rambut (megambahan rambut) pada saat ngayah mempersiapkan sarana upacara (banten). Untuk menjaga kesucian yadnya tersebut, juga dilarang bagi wanita yang sedang datang bulan untuk mengikuti prosesi upacara. Tata aturan itu juga berlaku bagi mereka yang dalam keadaan berduka (sebel). Memukul anjing juga tidak dibenarkan dilakukan saat yadnya dilaksanakan karena tindakan memukul adalah cetusan kemarahan yang harus dikendalikan dalam pelaksanaan yadnya, sehingga tidak menodai kesucian yadnya itu sendiri.

Nilai pendidikan acara dalam upacara $\mathrm{Paca}$ ruan Sasih Kaenem di Desa Pakraman Tonja, Kota Denpasar sudah dilaksanakan secara integral. Hal ini menjadi pengalaman empiris yang diterima umat Hindu dan menjadi sumbangan pengetahuan berharga untuk memperkaya pengetahuan yang dimiliki sebelumnya. Nilai pendidikan yang penting dipetik dari sini adalah disiplin dan konsistensi dalam tindakan. Seperti ditegaskan bahwa tempat, waktu, sarana dan prasarana, perangkat upacara, mantra dan sebagainya telah ditetapkan melalui aturan-aturan tertentu, karena itu merupakan kebenaran. Artinya, disiplin diri dan konsistensi untuk melaksanakan aturan-aturan tersebut merupakan kebenaran yang harus ditegakkan dan dilaksanakan secara terus-menerus.

\subsection{Proses Transmisi Nilai Didaktis dalam Upacara Pacaruan Sasih Kae- nem}

Upacara Pacaruan Sasih Kaenem di Pura Pasek Ngukuhin, Desa Pakraman Tonja, Denpasar telah menjadi tradisi keagamaan. Dalam konteks pendidikan, tradisi keagamaan harus membangun sebuah mekanisme masyarakat untuk beradaptasi dengan lingkungan dan perubahannya. Dalam hal ini, pendidikan mengambil fungsi sosialisasi dan internalisasi nilai-nilai kolektif dalam rangka membangun keteraturan, ketertiban, dan keseimbangan sosial di masyarakat (Maliki, 2010:42). Teori ini berkaitan dengan pandangan teori konstruktivistik dan belajar bermakna bahwa pendidikan harus mampu membangun pengetahuan peserta didik berdasarkan sesuatu yang bermakna (meaningfull construct). Pewarisan nilai tersebut dilakukan melalui (a) ideologi religius, (b) mitos, dan (c) sistem sosial.

Upacara Pacaruan Sasih Kaenem di Pura Pasek Ngukuhin, Desa Pakraman Tonja, Denpasar dapat dipandang sebagai lingkungan belajar tempat berlangsungnya proses pendidikan tersebut. Oleh karena itu, transmisi nilai melalui ideologi religius berlangsung secara simultan dan berkesinambungan dalam tradisi tersebut. Proses transmisi nilai melalui ideologi religius tradisi merupakan proses penyaluran nilai guna memelihara dan membangkitkan kesadaran religius umat Hindu. Hal ini sejalan dengan pendapat Elliade (dalam Susanto,1987:44-45) bahwa agama berfungsi membangkitkan dan menjaga kesadaran religius manusia mengenai Yang Sakral. "Yang Sakral" oleh umat beragama disebut Tuhan, para dewa, dan sebutan lainnya merupakan objek penghormatan dan penyembahan, yang disertai dengan doa, sajian, dan korban. Seluruh bentuk simbolisme menjadi ekspresi religius yang mengungkapkan pengalaman dan penghayatan keagamaan.

Ideologi religius ini tampak dari simbolis Barong Ket dan Rangda sebagai perwujudan Bhatara Siwa dan Bhatari Durga yang selalu dihadirkan (katedunan) dalam upacara Pacaruan Sasih Kaenem di Pura Pasek Ngukuhin, Desa Pakraman Tonja. Kejelasan tentang fungsi Barong Ket dan Rangda sebagai simbolis Hyang Widhi juga dapat dilihat dari adanya palinggih $\mathrm{Ge}$ dong Ratu Ngurah dan Ratu Ayu di Pura Pasek Ngukuhin yang menjadi sthananya. Fungsi Barong Ket dan Rangda dalam upacara Pacaruan Sasih Kaenem di Desa Pakraman Tonja adalah pamuput upacara dan ritual napak caru. Dalam prosesi Pacaruan tersebut, perwujudan Bhatara Siwa sebagai Barong Ket dan Bhatari Durga sebagai Rangda yang napak caru menjadi simbol bahwa Ida Bhatara atau Tuhan sendirilah yang turun ke dunia untuk menyelesaikan seluruh 
prosesi ritual tersebut.

Kesempurnaan yang dimaksud bahwa fungsi religius yang terkandung dalam pelaksanaan Pacaruan Sasih Kaenem telah sejalan dengan maksud dan tujuannya sebagai upacara bhuta yadnya. Dari berbagai mitos terkait dengan fungsi Bhatara Siwa dan Bhatari Durga dalam proses upacara bhuta yadnya menegaskan bahwa kehadiran Bhatara Siwa dan Dewi Durga ke dunia untuk nyomya (menyucikan) seluruh alam semesta berserta isinya dari gangguan para bhuta kala. Dalam prosesi upacara Pacaruan Sasih Kaenem tersebut juga terkandung simbol-simbol magis, terutama tampak dari prosesi napak caru yang selalu diikuti dengan para papatih yang kerauhan dan ngurek. Ini menandakan bahwa kehadiran Ida Bhatara ke dunia untuk menyelesaikan caru tersebut membawa vibrasi magis ke lingkungan sekelilingnya.

Dengan suksesnya ritual tersebut, tujuan umat Hindu untuk memperoleh keselamatan, perlindungan, dan terhindar dari segala mara bahaya yang disebabkan oleh gangguan para bhuta kala itu dapat diwujudkan. Berikutnya, kekuatan gaib yang diyakini muncul dari prosesi ritual tersebut disebarluaskan pengaruhnya kepada umat Hindu di seluruh wilayah Tegeh Kuri melalui upacara Ida Bhatara Malancaran (melakukan perjalanan suci). Melalui prosesi ini, terlihat jelas bahwa masyarakat Desa Pakraman Tonja, khususnya Banjar Tegeh Kuri percaya bahwa kekuatan Bhatara Siwa dan Bhatari Durga yang diwujudkan dengan Barong Ket dan Rangda Melancaran dapat memberikan keselamatan kepada seluruh warga masyarakat yang ada di wilayah tersebut.

Dengan demikian, upacara Pacaruan Sasih Kaenem di Desa Pakraman Tonja merupakan upacara keagaman yang mengandung unsur religius magis (magico religious). Aspek religius magis ini memberikan pengaruh kepercayaan yang kuat terhadap umat Hindu khususnya di wilayah Banjar Tegeh Kuri untuk selalu melaksanakan upacara Pacaruan Sasih Kaenem. Ideologi merupakan pandangan yang diyakini kebenarannya, serta mendorong seseorang untuk melakukan tindakan demi kepercayaannya tersebut. Dengan demikian, proses transmisi nilai didaktis upacara Pecaruan Sasih Kaenem dapat berlangsung melalui ideologi religius yang menjadikan tradisi keagamaan tersebut tetap dapat bertahan (survive) dan berkelanju- $\tan$ (sustainable).

Upacara Pacaruan Sasih Kaenem yang berkaitan dengan tapakan Barong Ket dan Rangda di Pura Pasek Ngukuhin sesungguhnya juga dikukuhkan melalui mitos yang berkembang di Desa Pakraman Tonja terutama pada masyarakat Tegeh Kuri. Keberadaan Barong Ket dan Rangda di Pura Pasek Ngukuhin dipandang sebagai peristiwa yang bersejarah. Peristiwa ini memunculkan rentetan peristiwa yang pada akhirnya menunjukkan kekuatan magis dan mistis dari tapel tersebut. Sampai akhirnya, tapel ini disakralkan dan disthanakan di Pura Pasek Ngukuhin sebagai sungsungan atau orientasi pemujaan krama Tegeh Kuri, Desa Pakraman Tonja. Malahan peristiwa dengan nuansa magis, seperti menyakiti (nyakitin) orang yang berlaku semena-mena terhadap tapakan tersebut semakin memepertebal keyakinan krama terhadapnya.

Jadi, upacara Pacaruan Sasih Kaenem berkenaan dengan mitos dan keyakinan mistis. Menurut Titus (1984:419) bahwa keyakinan mistis merangkum seluruh keyakinan manusia kepada yang gaib, kekuatan-kekuatan magis, dan berbagai jenis pengetahuan yang suprarasional. Keyakinan mistis dibangun oleh mitos, agama, dan intuisi yang menyebabkan munculnya perilaku mistis. Dalam hal ini, keyakinan pada kekuatan gaib dan magis Barong Ket dan Rang$d a$ dipandang dapat melindungi masyarakat dari berbagai ancaman dan gangguan. Apalagi terjadi peristiwa mistis dalam pelaksanaan upacara Pacaruan Sasih Kaenem, maka upacara ini akan diyakini keberhasilannya dan menjadi pedoman tindakan untuk waktu-waktu berikutnya sehingga secara langsung maupun tidak, akan melanggengkan tradisi tersebut.

Upacara atau ritual bukan semata-mata pengungkapan kesadaran magis-religius, tetapi juga berkaitan dengan upaya masyarakat untuk memenuhi kebutuhan religius dalam kehidupan sosialnya melalui kesadaran kolektif atas simbol-simbol yang disepakati bersama. Dalam konteks ini, kesadaran kolektif masyarakat Tegeh Kuri, Desa Pakraman Tonja dalam upacara Pacaruan Sasih Kaenem di Pura Pasek Ngukuhin telah dibangun dalam kurun waktu yang panjang. Kesadaran kolektif ini dipelihara terusmenerus melalui rutinisasi ritual bersama sehingga solidaritas dan integritas antarsesama warga tetap terjaga. Kbutuhan sosioreligius yang bersangkut-paut dengan upacara Pacaru- 
an Sasih Kaenem telah mengatasi kesadaran individu dan kelompok sehingga mau menerima ritual tersebut menjadi ritual kolektif seluruh krama Tegeh Kuri, bahkan Desa Pakraman Tonja yang turut terlibat di dalamnya. Kesadaran kolektif ini tidak terlepas dari kebutuhan masyarakat Banjar Tegeh Kuri dalam kehidupan religiusnya terutama untuk memohon keselamatan dan perlindungan Ida Sang Hyang Widhi Wasa.

Hal ini sejalan dengan pandangan Parson (Ritzer \& Goddman, 2005:121) bahwa setiap sistem harus mampu berintegrasi komponen lain yang saling berhubungan dalam struktur sosial yang lebih besar. Kebutuhan untuk berintegrasi dalam sistem sosial yang lebih luas, tampaknya mendorong krama Desa Pakraman Tonja untuk memperluas fungsi sosial religius. Agama menciptakan suatu ikatan bersama, baik di antara anggota-anggota beberapa masyarakat maupun dalam kewajiban-kewajiban sosial yang mempersatukan mereka. Menurut Wach (dalam Kahmad, 2002:15), agama dan masyarakat saling mempengaruhi dan saling bergantung (interdependence) dengan semua faktor yang ikut membentuk struktur sosial di masyarakat manapun. Smith (Koentjaraningrat, 1987:67) berpandangan bahwa setiap ritus dan upacara keagamaan yang dilaksanakan warga masyarakat pemeluk religi atau agama mempunyai fungsi sosial untuk mengintensifkan solidaritas masyarakat. Selain itu, Van Gennep juga menyatakan bahwa ritus dan upacara religi yang dilaksanakan oleh masyarakat secara berulang dengan interval waktu tertentu berfungsi sebagai "regenerasi" semangat kehidupan sosial dalam jiwa para warganya (Koentjaraningrat, 1987:74).

Berdasarkan uraian di atas dapat dipahami bahwa transmisi nilai didaktis upacara Pacaruan Sasih Kaenem dilakukan melalui tiga hal, yaitu melalui ideologi religius, melalui mitos, dan melalui sistem sosial. Transmisi nilai melalui ideologi religius dilaksanakan dengan membangun kepercayaan religius tentang upacara $\mathrm{Paca-}$ ruan Sasih Kaenem sehingga mampu menggerakkan tindakan masyarakat untuk melaksanakan upacara tersebut secara terus-menerus. Transmisi nilai melalui mitos berkaitan dengan kepercayaan magis dan mistis dari upacara $\mathrm{Pa}$ caruan Sasih Kaenem. Transmisi nilai melalui sistem sosial dilaksanakan dengan membangun solidaritas dan integrasi sosial seluruh krama
Tegeh Kuri dan Desa Pakraman Tonja untuk melaksanakan ritual tersebut secara bersamasama. Dengan berjalannya seluruh proses transmisi nilai didaktis tersebut, maka kebertahanan dan keberlangsungan upacara Pacaruan Sasih Kaenem dapat dipertahankan sehingga terjadi proses sosialisasi, internalisasi, dan ekuilibrasi secara simultan.

\section{III.PENUTUP}

Prosesi upacara Pacaruan Sasih Kaenem di Pura Pasek Ngukuhin, Desa Pakraman Tonja, Kota Denpasar dapat dibagi menjadi tiga tahap, yaitu prosesi awal, prosesi inti, dan prosesi akhir. Prosesi awal meliputi penentuan waktu pelaksanaan upacara, serta persiapan sarana dan prasarana upacara. Prosesi inti meliputi upacara pacaruan di Pura Pasek Ngukuhin, dan Ida Bhatara Malancaran ke pertigaan Oongan, perempatan Tegeh Kuri - Benculuk, dan Pura Kahyangan Bantas. Prosesi akhir adalah mensthanakan kembali tapakan Barong Ket dan Rangda ke Gedong Ratu Ayu dan Ratu Ngurah Pura Pasek Ngukuhin dan upacara panyineb. Upacara Pacaruan Sasih Kaenem berkaitan erat dengan keberadaan Barong Ket dan Rangda sebagai sesuhunan yang disthanakan di Pura Pasek Ngukuhin.

Nilai didaktis dalam pelaksanaan upacara $\mathrm{Pa}$ caruan Sasih Kaenem di Pura Pasek Ngukuhin, Desa Pakraman Tonja, Kota Denpasar, meliputi nilai pendidikan tattwa bahwa upacara Pacaruan Sasih Kaenem mengajarkan kepercayaan dan pemujaan kepada Bhatara Siwa dan Bhatari Durga, yaitu manifestasi Ida Sang Hyang Widhi Wasa sebagai panyupat (pembersih atau pelenyap) segala pengaruh jahat; nilai pendidikan susila bahwa upacara Pacaruan Sasih Kaenem mengajarkan penyucian pikiran, perkataan, dan perbuatan (tri kaya parisudha) yang terkandung dalam seluruh prosesi pelaksanaan yadnya; dan nilai pendidikan acara bahwa upacara Pacaruan Sasih Kaenem mengajarkan pentingnya pelaksanaan yadnya sebagai ungkapan bhakti kepada Tuhan secara tulus ikhlas.

Transmisi nilai didaktis upacara Pacaruan Sasih Kaenem dilakukan melalui tiga hal, yaitu melalui ideologi religius, melalui mitos, dan melalui sistem sosial. Transmisi nilai melalui ideologi religius dilaksanakan dengan membangun kepercayaan religius tentang upacara Pacaruan 
Sasih Kaenem sehingga mampu menggerakkan tindakan masyarakat untuk melaksanakan upacara tersebut secara terus-menerus; Transmisi nilai melalui mitos berkaitan dengan kepercayaan magis dan mistis dari upacara Pacaruan Sasih Kaenem. Transmisi nilai melalui sistem sosial dilaksanakan dengan membangun solidaritas dan integrasi sosial seluruh krama Desa Pakraman Tonja dalam ritual tersebut. Proses transmisi nilai didaktis ini melalui proses sosialisasi, internalisasi, dan ekuilibrasi secara simultan.

\section{DAFTAR PUSTAKA}

Al-Bary, Dahlan Yakub. 2001. Kamus Sosiologi Antropologi. Surabaya: Penerbit Indah.

Bagus, Lorenz. 2002. Kamus Filsafat. Jakarta: Gramedia Pustaka Utama.

Budiningsih, C Asri. 2005. Pembelajaran Moral, Berpijak Pada Karakteristik Siswa dan Budayanya. Jakarta: PT Rineka Cipta.

Departemen Pendidikan Nasional. 2005. Kamus Besar Bahasa Indonesia. Jakarta: Balai Pustaka.

Djamarah, Syaiful Bahri dan Zain, Aswan. 2002. Strategi Belajar Mengajar. Cetakan Kedua (Edisi Baru). Jakarta: PT Rineka Cipta.

Freire, Paulo. 1984. Pendidikan Sebagai Praktik Pembebasan. Jakarta: Gramedia Pustaka Utama.

Geriya, I Wayan, dkk. 2010. Kebudayaan Unggul: Inventori Unsur-unsur Budaya Unggul Sebagai Basis Kota Denpasar Kreatif. Denpasar: Bappeda Kota Denpasar.

Gunadha, Ida Bagus. 2009. Desa Pakraman Sebagai Strategi Kebertahanan Adat Budaya dan Agama Hindu Bali. Denpasar: Kerjasama UNHI Denpasar dan Kanwil Departemen Agama Provinsi Bali.

Hadi. Y. Sumandiyo. 2006. Seni Dalam Ritual Agama. Yogyakarta: Buku Pustaka.

Hamalik, Oemar. 2001. Proses Belajar Mengajar. Bandung: Bumi Aksara.

Ihromi, T.O. (ed.). 2006. Pokok-pokok Antropologi Budaya. Jakarta: Yayasan Obor Indonesia.

Koentjaraningrat. 1987. Sejarah Teori Antropolgi I. Jakarta: UI- Pers.

2002. Kebudayaan Mentalitas dan Pembangunan. Jakarta: Gramedia Pustaka Utama.

Lubis, dkk. M.Safrinal. 2007. Jagat Upacara Indonesia dalam Dialek Yang Sakral dan Yang Profan. Yogyakarta: Ekspersibuku.

Maliki, Zainuddin. 2010. Sosiologi Pendidikan. Yogyakarta: UGM.

Mantra, Ida Bagus. 1996. Landasan Kebudayaan Bali. Denpasar: Yayasan Dharma Sastra.

Monier, Sir Williams Monier. 1990. Sanskrit - English Dictionary. New Delhi: Motillah Banarsidass.

Mulyasa. 2008. Filsafat Pendidikan Meneropong Undang-undang Nomor 20 Tahun 2003 tentang Sistem Penddikan Nasional. Jakarta: Remaja Rosda Karya.

Pidarta, Made. 2007. Landasan Kependidikan: Stimulus Ilmu Pendidikan Bercorak Indonesia. Jakarta: Rineka Cipta.

Saiful, Sagala. 2005. Konsep dan Makna Pembelajaran. Bandung: Alfabeta.

Suamba (ed), Ida Bagus Putu. 1996. Yajna Basis Kehidupan Sebuah Canang Sari. Denpasar: Warta Hindu Dharma.

Subagiasta, dkk. 1996. Acara Agama Hindu. Direktorat Jendral Bimbingan Masyarakat Hindu dan Budha.

Sudarma, I Nengah. 2000. "Acara Agama Hindu" Makalah disampaikan dalam Pendalaman Sradha Generasi Muda Hindu se Bali Kerjasama Pemda Bali dengan DPD TK I Bali Peradah Indonesia Hotel Segara Kedisan, Kintamani, Bangli, tanggal 12-16 Juli 2000.

Sudharta, Tjok Rai, dan Atmaja, Ida Bagus Oka Punia. 2001. Upadesa Tentang Ajaran-Ajaran Agama Hindu. Surabaya: Paramita.

Sudijono, Anas. 2006. Pengantar Evaluasi Pendidikan. Jakarta: PT. Raja Grafindo Persada. 
Suparno, Paul. 1997. Filsafat Konstruktivisme dalam Pendidikan. Yogyakarta: Kanisius.

Surakhmad, Winarno.2003. Pengantar Interaksi Mengajar - Belajar: Dasar-Dasar Metodologi Pengajaran. Bandung: Tarsito.

Susanto, P.S. Hari. 1987. Mitos Menurut Pemikiran Mircea Alliade. Yogyakarta. Kanisius.

Undang-undang Nomor 20 Tahun 2003 tentang Sistem Pendidikan Nasional.

Wesnawa, Ida Bagus Putu. 2004. Revitalisasi Kebudayaan Bali. Denpasar: DPRD Provinsi Bali.

Yamin, Moh. 2009. Menggugah Pendidikan Indonesia "Belajar dari Paulo Freire dan Ki Hajar Dewantara". Yogyakarta: Ar-Ruzz Media.

Zuriah, Nurul.2005. Pendidikan Moral dan Budi Pekerti dalam Prespektif Perubahan. Jakarta. Bumi Aksara. 